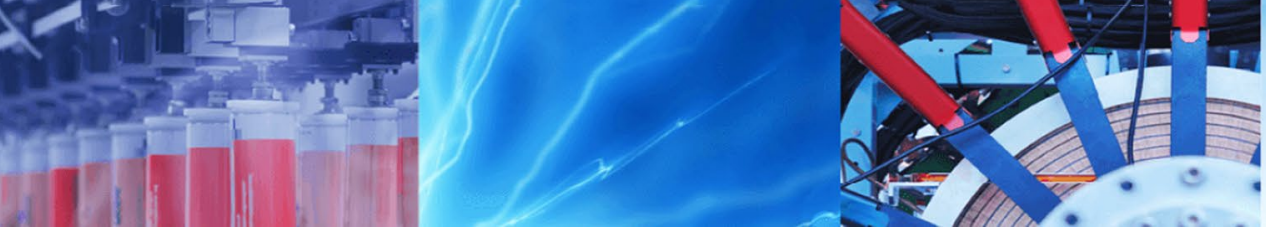

Research Article

\title{
Comparison of the removal of 21 micropollutants at actual concentration from river water using photocatalysis and photo-Fenton
}

\author{
Hawraa Ayoub ${ }^{1,2} \cdot$ Thibault Roques-Carmes $^{1}$. Olivier Potier ${ }^{1} \cdot$ Bachar Koubaissy $^{2} \cdot$ Steve Pontvianne $^{1}$. \\ Audrey Lenouvel $^{3}$. Cédric Guignard ${ }^{3}$. Emmanuel Mousset ${ }^{1} \cdot$ Hélène Poirot $^{1}$ - Joumana Toufaily ${ }^{2} \cdot$ Tayssir Hamieh $^{2}$
}

(c) Springer Nature Switzerland AG 2019

\begin{abstract}
The development of technologies capable of eliminating a wide spectrum of micropollutants of diverse nature from waters becomes essential. Advanced oxidation processes (AOPs) seem to be the most promising technologies but the most appropriate AOP to remove the micropollutants is still under debate. In this study, for the first time, the comparison of the efficiency of $\mathrm{TiO}_{2}$ heterogeneous photocatalysis and iron-impregnated faujasite heterogeneous photo-Fenton process is conducted towards the removal of a mixture of 21 micropollutants from a real river at low concentrations. The sampling area is situated on the Meurthe River, downstream the wastewater treatment plant of the city of Nancy in the northeast of France. To assess the impact of the micropollutants concentration and the matrix composition, two sampling campaigns have been performed at different periods of the year. Among the targeted micropollutants, 14 pharmaceuticals, 1 personal care product, 4 endocrine disruptors and 2 perfluorinated molecules are specifically followed. Their concentrations range from few $\mathrm{ng} \mathrm{L}^{-1}$ to hundreds $\mathrm{ng} \mathrm{L}^{-1}$. The adsorption of all the micropollutants is higher onto the iron-impregnated faujasite compared to that onto $\mathrm{TiO}_{2}$ due to the larger surface area of the iron-impregnated faujasite. The iron-impregnated faujasite offers superior photo-Fenton oxidation efficiency towards the degradation of the micropollutants over the $\mathrm{TiO}_{2}$ photocatalysis system. For almost all the micropollutants, the contaminants are totally removed after $30 \mathrm{~min}$ by photo-Fenton while a longer period is necessary by photocatalysis. A relationship between the removal efficiencies and the octanol-water partition coefficient (log Kow) of each micropollutant has been extracted from the data. A further economic evaluation confirms that the photo-Fenton process is also the better in terms of cost.
\end{abstract}

Keywords Water treatments · Micropollutants removal $\cdot$ Photocatalysis $\cdot$ Heterogeneous photo-Fenton $\cdot \mathrm{TiO}_{2} \cdot$ Ironimpregnated faujasite

\section{Introduction}

One of the main environmental challenges of the twentyfirst century is the pollution of the lakes, rivers, streams and oceans. Among all the contaminants detected in water, a large concern has emerged about the occurrence of micropollutants of diverse chemical natures. Micropollutants are contaminants, which are present at trace levels ranging from $\mathrm{ng} \mathrm{L}^{-1}$ up to hundreds of $\mu \mathrm{g} \mathrm{L}^{-1}[1$, 2]. This category of pollutants notably includes pharmaceuticals, endocrine disruptors, hormones, personal care products and perfluorinated compounds. They can have

Electronic supplementary material The online version of this article (https://doi.org/10.1007/s42452-019-0848-y) contains supplementary material, which is available to authorized users.

$\triangle$ Thibault Roques-Carmes, thibault.roques-carmes@univ-lorraine.fr | ${ }^{1}$ Laboratoire Réactions et Génie des Procédés (LRGP), UMR CNRS 7274, Université de Lorraine, 1 Rue Grandville, 54001 Nancy, France. ${ }^{2}$ Laboratory of Materials, Catalysis, Environment and Analytical Methods, Faculty of Sciences I, Lebanese University, Campus Rafic Hariri, Beirut, Lebanon. ${ }^{3}$ Luxembourg Institute of Science and Technology (LIST), 41 Rue du Brill, 4422 Belvaux, Luxembourg.

SN Applied Sciences (2019) 1:836| https://doi.org/10.1007/s42452-019-0848-y 
a significant effect on water quality, living organisms and ecosystems. They can produce adverse effects even at very low concentrations [2-4]. The processes used in the conventional wastewater treatment plants (WWTPs) are not able to remove efficiently a great number of these biorecalcitrant contaminants $[4,5]$. Several reasons can explain this aspect. First, the micropollutants are biorecalcitrants to the biological degradation which might occur during the biological treatments. Second, the micropollutants are generally polar. Consequently, they are not adsorbed onto the sludge and they cannot be removed by sedimentation. For the same reason, they cannot be eliminated by the tertiary treatments (sand filtration, lagooning process). Third, the diversity of pollutants (macro and micro) with different physico-chemical properties entering inside the conventional WWTPs plays also a role. The operating conditions to remove all these pollutants are different while the reactors design and the operating conditions (flow-rate, etc.) inside the conventional WWTPs are mainly made to remove the macropollutants [6]. Consequently, micropollutants concentrations from $\mathrm{ng} \mathrm{L}^{-1}$ to $\mu \mathrm{g} \mathrm{L}^{-1}$ are commonly encountered at the outlet of the WWTPs and find their ways into rivers [7-9]. Other routes of contaminations exist. The leaching from farmlands and agricultural runoff, the infiltration inside fractured bedrocks are some examples.

The development of new kinds of technologies capable of eliminating a wide spectrum of micropollutants of diverse chemical natures becomes necessary. Physicochemical processes (adsorption, membrane technology) appear as auspicious methods [10-13] but they produce a transfer of pollution from the water to another materials, which need to be retreated in an additional step. Advanced oxidation processes (AOPs) seem to be the most promising technologies because they are able, under certain conditions, to totally mineralize the pollutants present in the water $[14,15]$. AOPs are based on the production of very strong oxidizing agents, the hydroxyl radicals, that are capable of degrading biorecalcitrant compounds [14, 15]. AOPs are particularly adapted to treat water at low pollutant concentrations and low or moderate flow-rates [15]. In addition, the kinetic of photodegradation by photocatalysis and photo-Fenton is quite slow. As an example, it can take several hours to reach the complete mineralization of water containing pollutants at concentration of $\mathrm{mg} / \mathrm{L}$. As a consequence, they are more efficient to remove in a sufficient short amount of time the micropollutants with concentrations of $\mathrm{ng} / \mathrm{L}$ and $\mu \mathrm{g} / \mathrm{L}$. Heterogeneous photocatalysis and photo-Fenton are one of the most efficient AOPs for the removal of organic compounds and micropollutants $[16,17]$.

Several studies demonstrated that photocatalysis and photo-Fenton processes are efficient to degrade a wide range of micropollutants under ideal laboratory solution conditions with contaminant concentrations ranging from $\mu \mathrm{L} \mathrm{L}^{-1}$ to $\mathrm{mg} \mathrm{L}^{-1}$ [18-23]. However, these large concentrations of micropollutants are not representative of those encountered in real surface waters (lakes, rivers). Recently, the removal of micropollutants has been studied using synthetic and real waters (WWTP effluents or water from rivers) spiked with solutions of model micropollutants [20-23]. Only very few studies worked with micropollutants, at low concentrations in the range of $\mathrm{ng} \mathrm{L}^{-1}$, from real water. The two processes appear efficient to remove several micropollutants, in the range of concentrations from 1 to $500 \mathrm{ng} \mathrm{L}^{-1}$, from real waters (outlet of drinking water treatment plant, effluent from a WWTP, real municipal effluent) [24-27].

However, the most appropriate AOP to remove the micropollutants is still under discussions. It appears that the comparison between the degradation performances of the AOPs concerns mainly heterogeneous photocatalysis and homogeneous photo-Fenton [28-32]. The general trend is that homogeneous photo-Fenton leads to better removal efficiency than that of $\mathrm{TiO}_{2}$ photocatalysis [28-31]. The comparison of the efficacy of heterogeneous photocatalysis and heterogeneous photo-Fenton is barely reported in the scientific literature. In addition, to our knowledge, no specific study has been conducted with the aim to compare the heterogeneous photocatalysis and heterogeneous photo-Fenton removal of various microcontaminants at concentrations of $\mathrm{ng} \mathrm{L}^{-1}$ from a real river water.

In this study, for the first time, the efficiency of classical $\mathrm{TiO}_{2}$ UV photocatalysis and photo-Fenton process with iron-impregnated faujasite is compared and tested towards the removal of 21 micropollutants from a real river. River water downstream a WWTP has been selected because it represents a real water system with different micropollutants at low concentrations (from few $n g \mathrm{~L}^{-1}$ to hundreds $\mathrm{ng} \mathrm{L}^{-1}$ ) and in real conditions related to matrix effect and other water contaminants. The contaminants studied are composed of pharmaceuticals, personal care products, endocrine disruptors and perfluorinated compounds. Two sampling campaigns were carried out at different periods of the year in order to modulate the microcontaminants concentration in addition to the matrix composition.

\section{Materials and methods}

\subsection{Water sampling}

Water samples were collected from the Meurthe River, close to the city of Nancy in the northeast of France. The 
samples were taken from a specific site called Moulin Noir. The site was situated downstream the WWTP. The exact position of the sampling site is given in Fig. S1 of the Supporting Information. The latitude and longitude coordinates were equal to $48^{\circ} 44.605^{\prime} \mathrm{N}$ and $6^{\circ} 10.865^{\prime} \mathrm{E}$, respectively. Two sampling campaigns were conducted on October 14th 2016 and March 17th 2017. On October 14th 2016, the weather was dry but cloudy. The air temperature was around $8^{\circ} \mathrm{C}$. On March 17th 2017, the sampling took place under a cloudy sky with atmospheric temperature of $10^{\circ} \mathrm{C}$. The volumetric flow-rates in Moulin Noir on October 14th 2016 and March 17th 2017 amounted to 9.28 and $35.40 \mathrm{~m}^{3} / \mathrm{s}$, respectively. The samples were collected from the middle of a bridge crossing the river to ensure the good mixing of the water. The water was collected using brown glass bottle (volume of $1 \mathrm{~L}$ ) surrounded by iron cover, to avoid its breakage, using a thick long ribbon that was dropped from the bridge into the river. The collected waters were filtrated by two processes. First, funnel and filter paper were employed to remove the bulk materials. Then, the water was filtrated using a glass-fiber filter of $1.2 \mu \mathrm{m}$ porosity followed by a cellulose acetate filter with a porosity of $0.45 \mu \mathrm{m}$. Then, the sampled waters were kept in dark glass bottles at a temperature of $4^{\circ} \mathrm{C}$.

To estimate the nature and amount of some of the water components, and particularly the macropollutants present in the water, various analyses were performed. Non-purgeable organic carbon (NPOC), total nitrogen (TN) and inorganic carbon (IC) were evaluated using a TOC-V $\mathrm{V}_{\mathrm{CSH}}$ analyzer (Shimadzu). The UV-visible absorbance spectra were obtained with a spectrophotometer (Cary 5G UV-Vis-NIR). The fluorescence spectra were recorded with a F-2500 fluorescence spectrophotometer. The apparatus operated in synchronous fluorescence mode under excitation wavelengths $\left(\lambda_{\mathrm{ex}}\right)$ ranging from 230 to $600 \mathrm{~nm}$ with $\Delta \lambda\left(\lambda_{\text {em }}-\lambda_{\text {ex }}\right)=50 \mathrm{~nm}$. $\lambda_{\text {em }}$ denoted the fluorescence emission wavelength. The concentrations of different ions $\left(\mathrm{Cl}^{-}\right.$, $\mathrm{CO}_{3}{ }^{2-}, \mathrm{SO}_{4}{ }^{2-}, \mathrm{NO}_{3}{ }^{-}$) were measured by ICS-3000 Reagent$\mathrm{Free}^{\mathrm{TM}}$ Ion Chromatography (RFIC ${ }^{\mathrm{TM}}$ ) using hydroxide eluents with a flow-rate of $1 \mathrm{~mL} / \mathrm{min}$ and AS18 $(4 \times 250 \mathrm{~mm})$ column.

\subsection{Adsorption, photolysis, photocatalysis and photo-Fenton experiments}

For photocatalysis experiments, the photocatalyst consisted of commercial Degussa $\mathrm{P} 25 \mathrm{TiO}_{2}$ particles constituted of $75 \%$ anatase and $25 \%$ rutile. A previously developed iron-impregnated faujasite was used to degrade the microcontaminants by heterogeneous photo-Fenton process. The catalyst was prepared by wet impregnation of iron (III) nitrate nonahydrate deposited onto the faujasite [33]. The faujasite contained $20 \mathrm{wt} \%$ of iron. The Table 1
Table 1 Comparison of the surface properties of the iron-impregnated faujasite and $\mathrm{TiO}_{2}$

\begin{tabular}{|c|c|c|c|c|c|}
\hline \multirow[t]{2}{*}{ Sample } & \multicolumn{2}{|c|}{ BET method } & \multicolumn{3}{|c|}{ t-Plot method } \\
\hline & $\begin{array}{l}\text { Specific } \\
\text { surface } \\
\text { area } \\
\left(\mathrm{m}^{2} \mathrm{~g}^{-1}\right)\end{array}$ & $\begin{array}{l}\text { Constant } \\
\mathrm{C}_{\mathrm{BET}}\end{array}$ & $\begin{array}{l}\text { Micropo- } \\
\text { res } \\
\text { surface } \\
\left(\mathrm{m}^{2} \mathrm{~g}^{-1}\right)\end{array}$ & $\begin{array}{l}\text { Non } \\
\text { micropo- } \\
\text { res } \\
\text { surface } \\
\left(\mathrm{m}^{2} \mathrm{~g}^{-1}\right)\end{array}$ & $\begin{array}{l}\text { Micropo- } \\
\text { res } \\
\text { volume } \\
\left(\mathrm{cm}^{3} \mathrm{~g}^{-1}\right)\end{array}$ \\
\hline $\begin{array}{l}\text { Iron- } \\
\text { impreg- } \\
\text { nated } \\
\text { faujasite }\end{array}$ & 640 & 795 & 400 & 244 & 0.14 \\
\hline $\mathrm{TiO}_{2}$ & 59 & 200 & - & - & - \\
\hline
\end{tabular}

summarizes some of the properties of the two catalysts. In the previous paper [33] we developed the synthesis of the iron-impregnated faujasite. In addition, the photo-Fenton process was optimized in terms of $\mathrm{pH}, \mathrm{H}_{2} \mathrm{O}_{2}$ content, iron content deposited onto the faujasite, and light intensity. This optimization was conducted using macropollutant as well as micropollutants sampled from the Meurthe River. The sampling period and also the sampling position were different from those utilized here. However, in the previous study, the number of micropollutants with initial concentrations lower than the limit of quantification of the LC-MS/MS was relatively high. For this reason, in the present work, the water was sampled in a different position (in the site called Moulin Noir) and also at different periods of the year to work with larger amounts of different micropollutants at various concentrations. In addition, in the present study, the photo-Fenton removal experiments were directly conducted under the optimized conditions.

The experiments were carried out, at room temperature, in glass crystallizers. The reaction media was illuminated with a mercury lamp (low-pressure mercury arc, $18 \mathrm{~W}$, wavelength of $254 \pm 12 \mathrm{~nm}$ ) placed vertically $3.5 \mathrm{~cm}$ far from the top of the crystallizer. The total fluence reaching the reaction media amounted to $10^{-6}$ Einstein $\mathrm{L}^{-1} \mathrm{~s}^{-1}$. For each photodegradation test, $600 \mathrm{~mL}$ of water sample was utilized because a minimum volume of $500 \mathrm{~mL}$ was needed to perform a reliable quantification of all the micropollutants. In order to conduct the experiments with our conventional photocatalytic experimental assembly currently used in our previous works [34, 35], the volume of water was divided into 3 crystallizers of $200 \mathrm{~mL}$ each. An amount of $0.2 \mathrm{~g}$ of catalyst, i.e. $\mathrm{TiO}_{2}$ or iron-impregnated faujasite, was dispersed into $200 \mathrm{~mL}$ of the water sampled from the river for each reactor. Only for the photo-Fenton degradation tests, the experiments were performed in the presence of $0.007 \mathrm{~mol} / \mathrm{L}(0.238 \mathrm{~g} / \mathrm{L})$ of $\mathrm{H}_{2} \mathrm{O}_{2}$. This amount of $\mathrm{H}_{2} \mathrm{O}_{2}$ was chosen based on the optimization and effect of several criteria studied before [33]. It corresponded to a 
ratio $\left[\mathrm{H}_{2} \mathrm{O}_{2}\right] /[\mathrm{Fe}]=0.4$ which ensured a total reaction of the used $\mathrm{H}_{2} \mathrm{O}_{2}$, avoiding its presence at the end of the reaction. For each experiment, the three reactors worked in parallel. The suspensions containing the micropollutants were kept under magnetic stirring in the dark during $2 \mathrm{~h}$. This step appeared necessary to ensure the adsorption equilibrium [36] and evaluate the adsorption capacity of the catalysts towards the micropollutants. After completion of this step, the lamp was switched on. The degradation tests were conducted during $30 \mathrm{~min}$ or $6 \mathrm{~h}$ under UV irradiation and magnetic stirring. No intermediate sampling was performed during the experiments. At the end of the process, the whole treated waters from the three reactors were recovered and mixed together. The treated water was centrifuged for $25 \mathrm{~min}$ at $4000 \mathrm{rpm}$ in order to separate the particles from the solution.

The waters used for the photocatalysis and photo-Fenton degradation tests were the same. They were collected on October 14th 2016 and March 17th 2017. The water samples were treated by photo-Fenton the same day or, at least, $24 \mathrm{~h}$ after the photocatalytic reactions. The only difference between the two experiments was the nature of the catalyst $\left(\mathrm{TiO}_{2}\right.$ vs iron-impregnated faujasite) and the presence of $\mathrm{H}_{2} \mathrm{O}_{2}$ during the photo-Fenton process. Note also that the photolysis tests were conducted in the absence of catalyst and $\mathrm{H}_{2} \mathrm{O}_{2}$. Every experiment was repeated three times, and the data presented below are the averages of the repeated results.

\subsection{Micropollutants detection and quantification}

Before the quantification of the micropollutants by LC-MS/ MS, a concentration step by solid-phase extraction (SPE) was necessary. The solution was adjusted to $\mathrm{pH} 4$ by adding concentrated sulfuric acid. $550 \mathrm{~mL}$ of water sample were concentrated 1100 times by SPE using an Autotrace SPE Workstation (Thermo Fisher Scientific). The SPE phase (Oasis HLB 200 mg/6 mL, Waters) was successively conditioned with methanol, followed by ultra-pure water at $\mathrm{pH}$ 4. After the sample loading, the cartridge was successively cleaned with a $95 / 5(\mathrm{v} / \mathrm{v})$ water/methanol mixture, dried under a stream of nitrogen, and finally eluted with $10 \mathrm{~mL}$ of methanol. The extract was evaporated under vacuum at $50{ }^{\circ} \mathrm{C}$ to the drop and recovered in $500 \mu \mathrm{L}$ of water/ methanol $90 / 10(\mathrm{v} / \mathrm{v})$. All the eluents were of ultra-pure grade. The final extract was analyzed by liquid chromatography (1260 Series, Agilent) coupled to triple-quadrupole mass spectrometry (QTRAP 4500, AB Sciex). The chromatographic separation was conducted on a Zorbax Eclipse Plus C18 column ( $150 \times 2.1 \mathrm{~mm}$ ID, $3.5 \mu \mathrm{m}$ particle size, Agilent). The flow-rate of the mobile phase was fixed to $0.25 \mathrm{~mL} /$ min while the temperature of the oven was maintained at $40^{\circ} \mathrm{C}$. The detailed nature of the mobile phases and the eluent programs are given in the Supporting Information (Table S1 of the Supporting Information). The mass spectrometer was operated in positive or negative electrospray mode depending on the target molecules (Table S2 of the Supporting Information). Two transitions were recorded in Multiple Reaction Monitoring mode for quantification and confirmation of each target compound. Quantitative results were provided thanks to internal calibrations.

We focused our analysis on twenty-one micropollutants. They were selected based on several factors including the usage (pharmaceuticals, hormones, and industrial compounds), the health concern, the occurrence in the municipal wastewater and water systems, and the physicochemical properties. These contaminants belonged to four different families, which are pharmaceuticals, personal care products, endocrine disruptors and perfluorinated compounds. The Table S2 in the Supporting Information provides more information about the selected contaminants.

We are aware that by-products can be produced during the water treatment and, thus, participate to the overall toxicity of the treated samples. However, the LC-MS/MS analysis described in this study was performed in Multiple Reaction Monitoring (MRM) mode, to ensure the best sensitivity and reliability of the measurements. As a matter of fact, this method offered very good performances, but was specific to the targeted analytes. So, the potential degradation products cannot be detected. The detection of byproducts, even if fully relevant, would have required a "full scan" LC-MS method to allow the detection of unknown compounds, but with much higher quantification limits. Considering our aims in this study, we choose to give the priority to the sensitivity and ensure the detection of the target analytes at environmental concentration levels.

\section{Results and discussion}

\subsection{Characterization of the matrix}

Preliminary experiments were undertaken to evaluate the amount and the nature of some of the water components, and particularly, the macropollutants present in the water. They are representative of the matrix containing the targeted microcontaminants. The results of the analyses are summarized in Table 2.

Dissolved organic matter (DOM), dissolved organic carbon (DOC), and biochemical oxygen demand (BOD) in the river water are studied through fluorescence spectrophotometry (Fig. S2a of the Supporting Information). For the two water samples, the presence of two main peaks is observed: tryptophan-like fluorescence $\left(\lambda_{\mathrm{ex}}=288 \mathrm{~nm}\right.$, $\lambda_{\mathrm{em}}=338 \mathrm{~nm}$ ) related to protein-like substances and 
Table 2 Comparison of the physicochemical characteristics of the two waters

\begin{tabular}{|c|c|c|}
\hline & October 2016 & March 2017 \\
\hline $\begin{array}{l}\text { Tryptophan-like fluores- } \\
\text { cence intensity (a.u.) }\end{array}$ & 126 & 50 \\
\hline $\begin{array}{l}\text { Fulvic acids fluorescence } \\
\text { intensity (a.u.) }\end{array}$ & 152 & 117 \\
\hline UV $A_{190}$ (a.u.) & 1.9 & 2.3 \\
\hline UV A $_{254}$ (a.u.) & 0.07 & 0.07 \\
\hline SUVA $\left(\mathrm{L} \mathrm{mg}^{-1}\right)$ & 2.5 & 2.2 \\
\hline $\mathrm{NPOC}\left(\mathrm{mg} \mathrm{L}^{-1}\right)$ & 4.36 & 4.08 \\
\hline $\mathrm{TN}\left(\mathrm{mg} \mathrm{L}^{-1}\right)$ & 2.42 & 2.08 \\
\hline $\mathrm{IC}\left(\mathrm{mg} \mathrm{L}^{-1}\right)$ & 30.33 & 24.83 \\
\hline $\mathrm{Cl}^{-}\left(\mathrm{mg} \mathrm{L}^{-1}\right)$ & 1040.59 & 1421.82 \\
\hline $\mathrm{CO}_{3}{ }^{2-}\left(\mathrm{mg} \mathrm{L}^{-1}\right)$ & 26.51 & 4.62 \\
\hline $\mathrm{SO}_{4}{ }^{2-}\left(\mathrm{mg} \mathrm{L}^{-1}\right)$ & 169.46 & 74.92 \\
\hline $\mathrm{NO}_{3}^{-}\left(\mathrm{mg} \mathrm{L}^{-1}\right)$ & 7.54 & 10.19 \\
\hline $\mathrm{pH}$ & 7.32 & 7.26 \\
\hline
\end{tabular}

fulvic acids fluorescence $\left(\lambda_{\mathrm{ex}}=355 \mathrm{~nm}, \lambda_{\mathrm{em}}=405 \mathrm{~nm}\right)$. The position of the two peaks is the same for the two waters indicating similar DOM nature [37]. Tryptophan-like fluorescence can be used as an indicator of domestic pollution concentration [38]. Fulvic acids fluorescence intensity is found to be very close between the waters collected in October (152 a.u.) and March (117 a.u.), which reflects a similar fulvic acid component content. This result is consistent with the NPOC values (or DOC) that show no significant difference between the two waters.

The UV-visible spectroscopic analysis gives an idea about the nitrate and nitrite species present in the river water from the absorbance peak at $190 \mathrm{~nm}\left(\mathrm{~A}_{190}\right.$, Fig. S2b of the Supporting Information). Similar intensities are recorded for this peak for the two waters indicating similar inorganic nitrate content. This result is confirmed by the slight variation in the amount of nitrate species detected in the two samples. Moreover, the UV absorbance at $254 \mathrm{~nm}\left(\mathrm{~A}_{254}\right)$ has been found by most authors to be correlated to the DOM, the chemical oxygen demand $(C O D)$, and the TOC. Similar $A_{254}\left(A_{254}=0.07\right)$ are measured for the two samples. This is another indication for the close content nature of organic matter of the water matrices of the two waters. Specific UV absorbance (SUVA $=A_{254} \times 100 /$ DOC) gives an indication of the content of aromatic and unsaturated organic compounds and reflects the DOM type. The SUVA values for the two waters $\left(2.5 \mathrm{~L} \mathrm{mg}^{-1}\right.$ in October and $2.2 \mathrm{~L} \mathrm{mg}^{-1}$ in March) are close indicating similar aromatic organic carbon content [39].

The analysis of TN and IC in the two samples reflect also similar matrix content due to the relatively identical values recorded for the two samples (TN: 2.42 and $2.08 \mathrm{mg} \mathrm{L}^{-1}$, IC: 30.33 and $24.83 \mathrm{mg} \mathrm{L}^{-1}$ ). Concerning the ions, a variation
Table 3 Initial concentrations $\left(C_{0}\right)$ of the micropollutants inside the river water samples from March 2017 and October 2016

\begin{tabular}{lll}
\hline Micropollutants & $\begin{array}{l}\text { March 2017 } \\
\mathrm{C}_{0}\left(\mathrm{ng} \mathrm{L}^{-1}\right)\end{array}$ & $\begin{array}{l}\text { October 2016 } \\
\mathrm{C}_{0}\left(\mathrm{ng} \mathrm{L}^{-1}\right)\end{array}$ \\
\hline Bisphenol A & 54.4 & 88.4 \\
Carbamazepine & 18.9 & 75.8 \\
Carbamazepine 10,11-epoxide & $<$ & 3.3 \\
Clarithromycin & 16.0 & 703 \\
Cyclophosphamide & $<$ & $<$ \\
Diclofenac & 51.2 & 142 \\
Erythromycin & $<$ & 1006 \\
Beta-estradiol & $<$ & $<$ \\
Estrone & 4.4 & 6.8 \\
Ethinylestradiol & $<$ & $<$ \\
Ibuprofen & 22.5 & 20.7 \\
Ketoprofen & 6.9 & 7.7 \\
Lidocaine & 7.5 & 52.6 \\
Naproxen & 20.1 & 15.0 \\
PFOA & 0.8 & 2.9 \\
PFOS & 6.6 & 22.2 \\
Sulfadimethoxine & $<$ & $<$ \\
Sulfadimine & $<$ & $<$ \\
Sulfamethoxazole & 6.2 & 35.4 \\
Sulfathiazole & $<$ & $<$ \\
Triclosan & 13.3 & 14.4 \\
\hline
\end{tabular}

$<$ : pollutant concentration lower than the limit of quantification of the LC-MS/MS

has to be outlined between the amounts of $\mathrm{CO}_{3}{ }^{2-}, \mathrm{Cl}^{-}$, $\mathrm{NO}_{3}{ }^{-}$and $\mathrm{SO}_{4}{ }^{2-}$ detected inside the two water samples.

To summarize, it appears that the macropollution is not distinctly different between both water samples. A slight matrix effect in terms of organic compounds could be anticipated while a non-negligible effect of the ions may be obtained.

\subsection{Initial micropollutant concentrations}

In the first instance, the initial micropollutants concentrations from the two-sampled waters are considered (Table 3 ). The concentrations of cyclophosphamide, beta-estradiol, ethinylestradiol, sulfadimethoxine, sulfadimidine and sulfathiazole remain lower than the limit of quantification of the LC-MS/MS for the two waters. Consequently, the efficiency of the degradation process towards the removal of these micropollutants cannot be evaluated. For the other contaminants, their concentrations fall within the $\mathrm{ng} \mathrm{L}^{-1}$ levels, i.e. from few $\mathrm{ng} \mathrm{L}^{-1}$ to hundreds $\mathrm{ng} \mathrm{L}^{-1}$. The contaminants concentrations depend on many factors such as sampling date, time of the day, weather, raining periods, etc. The micropollutant amounts are lower in the water sampled in March than that collected in October. This is particularly true 
for the pharmaceutical compounds. This can be attributed to a more important utilization of drugs medicines in October than in March and difference of river flow-rates. As an example, the clarithromycin antibiotic is significantly more abundant in October $\left(703 \mathrm{ng} \mathrm{L}^{-1}\right)$ compared to that reported in March $\left(16 \mathrm{ng} \mathrm{L}^{-1}\right)$. The same conclusion can be drawn with sulfamethoxazole, which is another antibiotic. Another illustration of this aspect is given with erythromycin and carbamazepine 10,11-epoxide, with respective concentrations of 1006 and $3 \mathrm{ng} \mathrm{L}^{-1}$ in the water collected in October, whereas their contents are lower than the limit of quantification for the water sampled in March.

\subsection{Direct photolysis}

Photolysis experiments were conducted in the absence of catalyst under UV illumination for $30 \mathrm{~min}$ and $6 \mathrm{~h}$ (Fig. 1a). The photolysis efficiency can be estimated using:

Photolysis $=\left(\frac{C_{0}-C(t, U V)}{C_{0}}\right) \times 100$

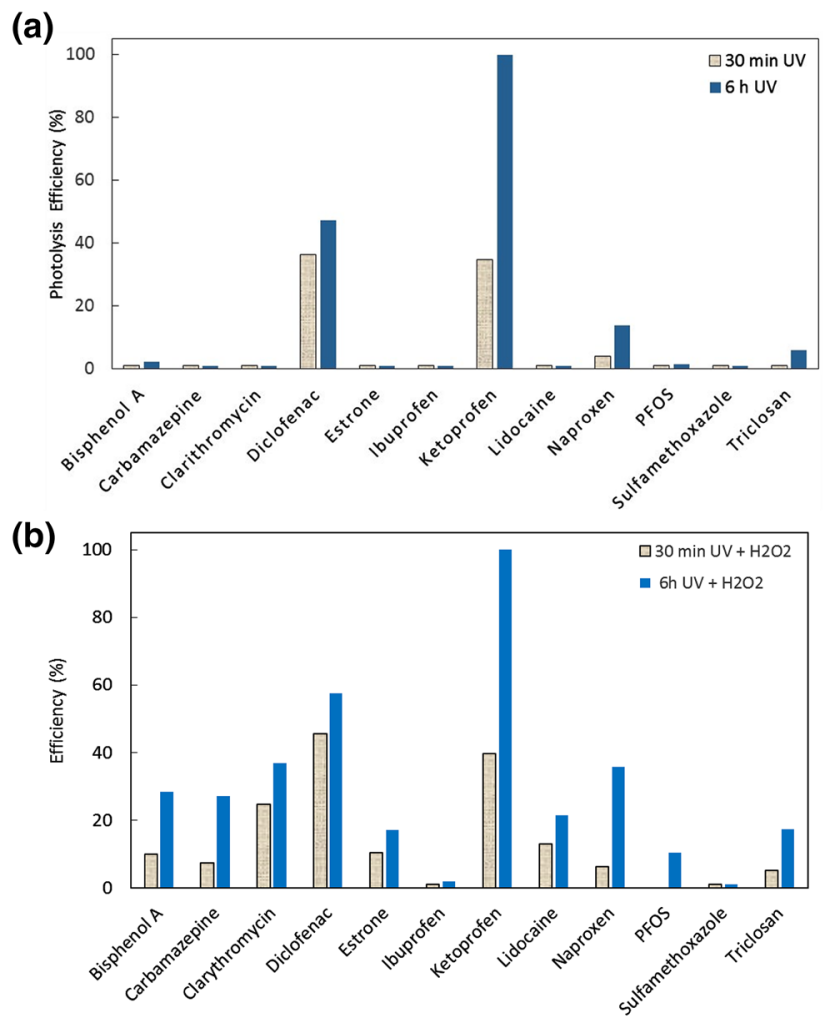

Fig. 1 a Photolysis efficiency towards the degradation of the micropollutants after $30 \mathrm{~min}$ ("30 min UV") and $6 \mathrm{~h}$ ("6 h UV") of UV treatment with river water sample from March 2017. b Blank experiments in the simultaneous presence of $\mathrm{UV}$ and $\mathrm{H}_{2} \mathrm{O}_{2}$ towards the degradation of the micropollutants after $30 \mathrm{~min}$ ("30 min $\mathrm{UV}+\mathrm{H}_{2} \mathrm{O}_{2}$ ") and $6 \mathrm{~h}$ (" $6 \mathrm{~h} \mathrm{UV}+\mathrm{H}_{2} \mathrm{O}_{2}$ ") of treatment with river water sample from March 2017 where $C_{0}$ is the initial micropollutant concentration, $C(t$, UV) represents the micropollutant concentration after $30 \mathrm{~min}(\mathrm{C}(30 \mathrm{~min}, \mathrm{UV}))$ or $6 \mathrm{~h}(\mathrm{C}(6 \mathrm{~h}, \mathrm{UV}))$ of UV treatment in the absence of catalyst.

For most of the micropollutants, no variation of the concentrations is detected after $30 \mathrm{~min}$ and $6 \mathrm{~h}$ of illumination. This emphasizes that the photolysis effect is negligible for bisphenol $A$, carbamazepine, clarithromycin, estrone, ibuprofen, lidocaine, PFOA, PFOS, sulfamethoxazole and triclosan (Photolysis $=0-6 \%$ ). Similar absence of photodegradation was previously reported for carbamazepine, clarithromycin and sulfamethoxazole [21, 40]. In addition, the negligible photolysis of estrone corresponds well to the results reported by Sornalingam et al. [23]. This behavior was attributed to the lack of light absorption by this pollutant. However, three microcontaminants need to be discussed. For naproxen, a slight photolysis effect is noticed since the photolysis efficiency becomes equal to $14 \%$ after $6 \mathrm{~h}$ of irradiation. The complete removal of ketoprofen occurs after $6 \mathrm{~h}$ of photolysis process (Photolysis $=100 \%$ ). It is difficult to discriminate between the photolysis and the photocatalytic or photo-Fenton effects during the degradation of this contaminant. In addition, the photolysis effect cannot be neglected with diclofenac since the photolysis efficiency reaches $47 \%$ after $6 \mathrm{~h}$ of illumination. Bernabeu and coworkers [40] reached the same type of conclusion. They indicated that the photolysis of diclofenac was around $10 \%$ for an initial concentration of $300 \mathrm{ng} \mathrm{L}^{-1}$.

A second set of degradation experiments were conducted, in the absence of catalyst, under UV illumination and in the presence of $\mathrm{H}_{2} \mathrm{O}_{2}$ (Fig. $1 \mathrm{~b}$ ). For the majority of the micropollutants, the simultaneous presence of light and $\mathrm{H}_{2} \mathrm{O}_{2}$ leads to greater degradation of the contaminants than the photolysis. The reaction between UV and $\mathrm{H}_{2} \mathrm{O}_{2}$ produces $\mathrm{OH}$ hydroxyl radicals. The larger degradation of the micropollutants is due to the presence of the $\mathrm{OH}$. The total degradation of ketoprofen takes place after $6 \mathrm{~h}$ of process. The degradation efficiency remains high for diclofenac (60\%), naproxen (40\%), clarithromycin (40\%), bisphenol A (30\%) and carbamazepine (30\%) after $6 \mathrm{~h}$ of process. On the opposite, the removal remains weak for triclosan, lidocaine, estrone, PFOS, while it is negligible for ibuprofen and sulfamethoxazole.

\subsection{Adsorption of the micropollutants onto $\mathrm{TiO}_{2}$ and iron-impregnated faujasite}

To investigate the adsorption of the micropollutants onto $\mathrm{TiO}_{2}$ and iron-impregnated faujasite, the contaminants concentration is analyzed after $2 \mathrm{~h}$ of contact between the water and the catalyst. The adsorption efficiency of the catalyst is given by: 
$\mathrm{R}_{\mathrm{a}}=\left(\frac{\mathrm{C}_{0}-\mathrm{C}(2 \mathrm{~h} \text { dark adsorption })}{\mathrm{C}_{0}}\right) \times 100$

where $\mathrm{C}(2 \mathrm{~h}$ dark adsorption) stands for the remaining contaminants concentration after $2 \mathrm{~h}$ of contact between the water and the catalyst. The adsorption efficiencies obtained with the two catalysts for the two samplings performed at different periods are reported in Fig. 2.

In the presence of $\mathrm{TiO}_{2}$, among all the quantified micropollutants, only carbamazepine-10,11-epoxide is totally

(a)

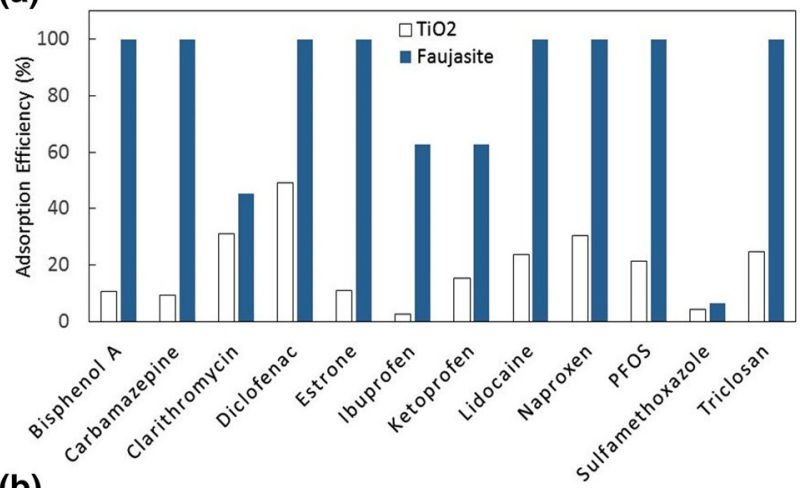

(b)

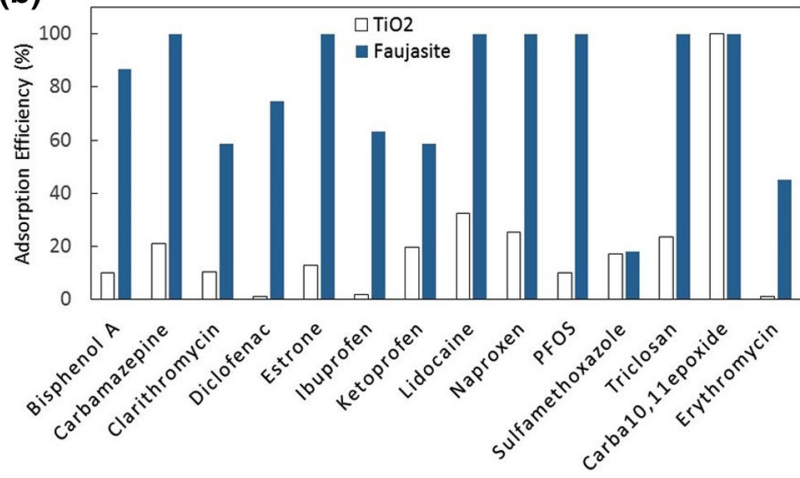

Fig. 2 Adsorption efficiency Ra of $\mathrm{TiO}_{2}\left({ }^{("} \mathrm{TiO}_{2}\right.$ ") and iron-impregnated faujasite ("Faujasite") towards the micropollutants from the waters sampled in a March 2017 and b October 2016. "carba10,11 epoxide" indicates carbamazepine 10,11-epoxide adsorbed after $2 \mathrm{~h}$ of stirring in the dark for the water sampled in October $2016\left(R_{a}=100 \%\right)$. The initial concentration of carbamazepine-10,11-epoxide is low $\left(3.3 \mathrm{ng} \mathrm{L}^{-1}\right)$ and close to its limit of quantification given as $3.0 \mathrm{ng} \mathrm{L}^{-1}$. The absence of adsorption of ibuprofen, PFOA and erythromycin onto $\mathrm{TiO}_{2}$ is also highlighted. For the other micropollutants, the adsorption efficiency $R_{a}$ ranges between 9 and $49 \%$, with the majority of the $R_{a}$ around $10-20 \%$. It can be concluded that the micropollutants adsorption remains low onto $\mathrm{TiO}_{2}$. Consequently, these micropollutants cannot be efficiently removed by adsorption over $\mathrm{TiO}_{2}$. This is not surprising since $\mathrm{TiO}_{2}$ possesses a low specific surface area $\left(59 \mathrm{~m}^{2} / \mathrm{g}\right)$ and no apparent porosity $[34,35]$.

The iron-impregnated faujasite displays a different behavior in terms of micropollutant adsorption. The complete adsorption $\left(R_{a}=100 \%\right)$ of carbamazepine, carbamazepine-10,11-epoxide, estrone, lidocaine, PFOS, naproxen and triclosan occurs regardless of the initial micropollutant concentration. At the same time, diclofenac and bisphenol $A$, are totally adsorbed onto the iron-impregnated faujasite for the river water sample from March 2017, which present the lower initial concertation. For the other micropollutants such as clarithromycin $\left(R_{a}=45-58 \%\right)$, erythromycin $\left(R_{a}=45 \%\right)$, ibuprofen $\left(R_{a}=62-63 \%\right)$ and ketoprofen $\left(R_{a}=58-62 \%\right)$, the adsorption efficiencies remain at a high level. Conversely, only for sulfamethoxazole $(R a=6-17 \%)$ and PFOA $\left(R_{a}=9-37 \%\right)$, the adsorption efficiency is low.

To summarize, the adsorbed amounts of all the micropollutants are higher onto the iron-impregnated faujasite compared to those onto $\mathrm{TiO}_{2}$. The better adsorption properties of the iron-impregnated faujasite are confirmed by carbon analysis performed with the sample of water collected in October (Table 4). The initial NPOC of $4.3 \mathrm{mg} \mathrm{C}$ $\mathrm{L}^{-1}$ decreases to 2.9 and $3.5 \mathrm{mg} \mathrm{C} \mathrm{L}^{-1}$ at the end of the adsorption period in the presence of iron-impregnated faujasite and $\mathrm{TiO}_{2}$, respectively. Analogously, the IC of $30.3 \mathrm{mg} \mathrm{CL}^{-1}$ drops to 16.1 and $25.3 \mathrm{mg} \mathrm{CL}^{-1}$ after contact with the iron-impregnated faujasite and the $\mathrm{TiO}_{2}$, respectively. These results can be explained by the surface area
Table 4 Concentration of non-purgeable organic carbon (NPOC) and inorganic carbon (IC) before and after treatment by photocatalysis with $\mathrm{TiO}_{2}$ and by photo-Fenton with iron-impregnated faujasite in river water sample from October 2016

\begin{tabular}{lllll}
\hline Time & $\begin{array}{l}\text { Photocatalysis } \\
\mathrm{TiO}_{2} \\
\mathrm{NPOC}\left(\mathrm{mg} \mathrm{CL}^{-1}\right)\end{array}$ & $\begin{array}{l}\text { Photo-Fenton } \\
\text { Iron-impregnated } \\
\text { faujasite } \\
\mathrm{NPOC}\left(\mathrm{mg} \mathrm{CL}^{-1}\right)\end{array}$ & $\begin{array}{l}\text { Photocatalysis } \\
\mathrm{TiO}_{2} \\
\mathrm{IC}\left(\mathrm{mg} \mathrm{CL}^{-1}\right)\end{array}$ & $\begin{array}{l}\text { Photo-Fen- } \\
\text { ton } \\
\text { Iron- } \\
\text { impregnated } \\
\text { faujasite } \\
\mathrm{IC}\left(\mathrm{mg} \mathrm{CL}^{-1}\right)\end{array}$ \\
\hline $\begin{array}{llll}\text { Initial } \\
0(2 \text { h adsorption })\end{array}$ & 3.36 & 4.36 & 30.33 & 30.33 \\
30 min & 3.51 & 2.91 & 25.31 & 16.18 \\
$6 \mathrm{~h}$ & 3.01 & 2.65 & n.m. & n.m. \\
\hline
\end{tabular}

n.m. not measured 
of iron-impregnated faujasite $\left(640 \mathrm{~m}^{2} \mathrm{~g}^{-1}\right)$ that is greater than the one of $\mathrm{TiO}_{2}\left(59 \mathrm{~m}^{2} \mathrm{~g}^{-1}\right)$.

\subsection{Degradation of the micropollutants through photocatalysis and photo-Fenton processes}

The photocatalytic and photo-Fenton removal of the micropollutants is studied. After the adsorption period, the concentrations of the different compounds are estimated after $30 \mathrm{~min}$ and $6 \mathrm{~h}$ under UV irradiation in the presence of $\mathrm{TiO}_{2}$ or iron-impregnated faujasite. The removal percentage can be expressed as:

$X(t)=\left(\frac{C_{0}-C(t)}{C_{0}}\right) \times 100$

where $C(t)$ represents the micropollutant concentration after $30 \mathrm{~min}(\mathrm{C}(30 \mathrm{~min}))$ or $6 \mathrm{~h}(\mathrm{C}(6 \mathrm{~h}))$ of process (photocatalysis or photo-Fenton). Note that the removal percentage of $100 \%$ does not necessarily indicate the complete mineralization of the contaminant. For instance, a weak carbon content $\left([\mathrm{NPOC}]=2.67 \mathrm{mg} \mathrm{CL}^{-1}\right.$ and $2.44 \mathrm{mg} \mathrm{CL}^{-1}$ ) remains after $6 \mathrm{~h}$ of photocatalysis and photo-Fenton for the water sampled in October (Table 4). These carbon contents correspond to the whole matrix, which might include some originating by-products produced during the degradation and/or the other micro or macrocontaminants not degraded by the process. The low carbon content ([NPOC]) measured at the end of the reactions, is an important indication for high mineralization of the micropollutants and negligible toxicity.

The removal percentages are given in Fig. $3 a, b$ for the sampling performed in March and October, respectively. In a first approach, to compare the efficiency of the two processes, the results are discussed based on the removal efficiency after $6 \mathrm{~h}$ of process $(X(6 \mathrm{~h}))$. During $6 \mathrm{~h}$ of photocatalytic and photo-Fenton treatments, the main part of the micropollutants is removed, i.e. $X(6 \mathrm{~h})$ equals $100 \%$. Carbamazepine, carbamazepine-10,11-epoxide, clarithromycin, diclofenac, estrone, ketoprofen, lidocaine, naproxen and triclosan are totally removed by the two processes for the two initial concentrations. For the other micropollutants, the removal percentage is generally greater using the photo-Fenton process than with the photocatalytic degradation. For bisphenol A and PFOS, X(6 h) increases, respectively, from $65-75 \%$ to $94-100 \%$, and from $36-56 \%$ to $88-100 \%$, when the $\mathrm{TiO}_{2}$ photocatalyst is replaced by the photo-Fenton catalyst. However, the removal efficiency towards ibuprofen is similar for the two processes $(X(6 \mathrm{~h})=93-100 \%)$. Conversely, the photocatalytic process leads to the total degradation of initial sulfamethoxazole concentrations of 35 and $6 \mathrm{ng} \mathrm{L}^{-1}$, while the photo-Fenton (a)

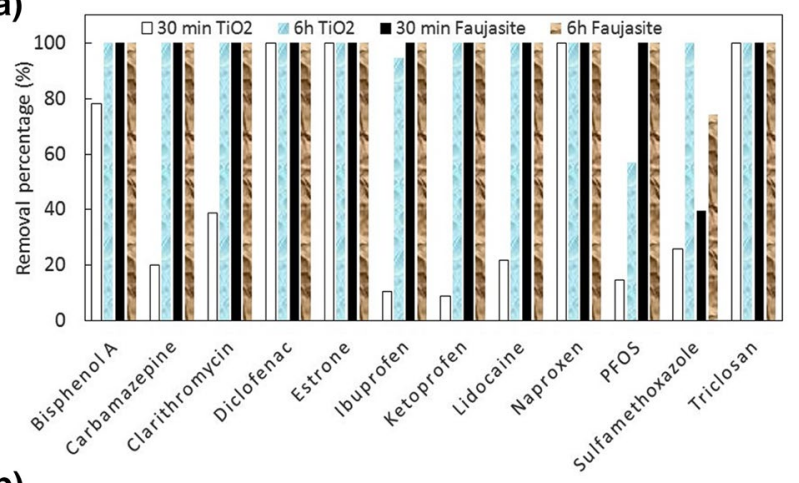

(b)

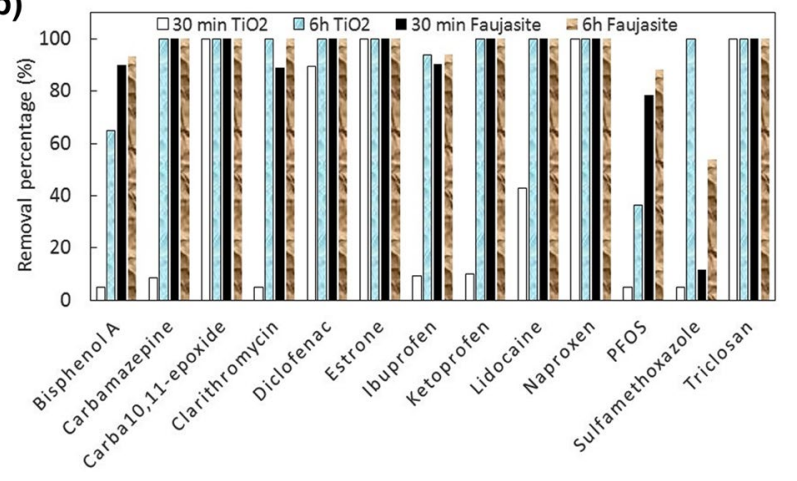

Fig. 3 Removal percentages of the micropollutants by photocatalysis with $\mathrm{TiO}_{2}$ catalyst (" 30 min $\mathrm{TiO}_{2}$ ", " $6 \mathrm{~h} \mathrm{TiO}_{2}$ ") and by photo-Fenton using iron-impregnated faujasite system ("30 min Faujasite", "6 h Faujasite") from the waters sampled in a March 2017 and b October 2016. "carba10,11 epoxide" indicates carbamazepine 10,11-epoxide

treatment produces only partial degradation with $\mathrm{X}(6 \mathrm{~h})$ values of $54 \%$ and $74 \%$, respectively. The photocatalytic performances are similar to those described by MirallesCuevas et al. [26] for the photodegradation of diclofenac and naproxen. The authors reported a total disappearance of $1500 \mathrm{ng} \mathrm{L}^{-1}$ of diclofenac and $3000 \mathrm{ng} \mathrm{L}^{-1}$ of naproxen after $4 \mathrm{~h}$ under solar light irradiation. At the same time, the complete removal of ibuprofen $\left(750 \mathrm{ng} \mathrm{L}^{-1}\right)$ was achieved in $2 \mathrm{~h}$. The degradation results are in accordance with the data reported by Bernabeu and coworkers [40] for the removal of clarithromycin, diclofenac and carbamazepine from a mixture containing nine emerging contaminants at concentrations around $50-100 \mathrm{ng} \mathrm{L}^{-1}$. The entire photocatalytic decomposition of sulfamethoxazole corresponds perfectly with previously reported findings $[41,42]$.

It appears interesting to find a relation between the removal efficiency and the physico-chemical characteristics of each micropollutant. The removal of micropollutants depends on their physico-chemical properties such as pKa, solubility, octanol-water partition coefficient Kow and Henry's constant. In the present study, log Kow, which is a hydrophobicity parameter, seems to play a role. The Table 5 lists the log Kow of the micropollutants with the removal percentages after $6 \mathrm{~h}$ of photocatalysis and 
Table 5 Relationship between the log Kow of the micropollutants with the removal percentages after $6 \mathrm{~h}$ of photocatalysis and photoFenton processes

\begin{tabular}{llll}
\hline Log Kow & Micropollutants & $\begin{array}{l}\text { Photocatalysis removal } \\
\text { percentage }\end{array}$ & $\begin{array}{l}\text { Photo-Fenton } \\
\text { removal percent- } \\
\text { age }\end{array}$ \\
\hline 0.79 & Sulfamethoxazole & 100 & $54-74$ \\
$2.16-3.1$ & Clarithromycin, Estrone, Carbamazepine, & 100 & 100 \\
& Lidocaine, Ketoprofen, Naproxen & & $94-100$ \\
3.32 & Bisphenol A & $65-75$ & $88-100$ \\
4.3 & PFOS & $36-56$ & \\
\hline
\end{tabular}

photo-Fenton processes. The log Kow of all the micropollutants range between 0.79 and 4.3. For the pollutant with low log Kow (0.79), the total removal of sulfamethoxazole occurs only with photocatalysis. Sulfamethoxazole has a very low Kow value (0.79) compared to the others micropollutants, for which low Kow are larger than or equal to 2.1. Consequently, sulfamethoxazole is the most polar micropollutant among the targeted pollutants. It has a higher interaction affinity with $\mathrm{TiO}_{2}$ for which the hydrophilic character is caused by the hydroxyl groups on the surface. On the opposite, the micropollutants with log Kow between 2.16 and 3.1 behave similarly with total removal under both processes. For the micropollutants with log Kow larger than or equal to 3.3, i.e. bisphenol A and PFOS, their total removal can be obtained by photo-Fenton while the photocatalysis process produces lower removal efficiency. Bisphenol A and PFOS have higher log Kow (3.3 and 4.3, respectively). They possess less hydrophilic character than the other micropollutants which lead to stronger interactions with the hydrophobic iron-impregnated faujasite.

In order to analyze the kinetic of degradation, it appears practical to discuss the removal efficiency after $30 \mathrm{~min}$ of process $(X(30 \mathrm{~min}))$. For almost all the micropollutants, the contaminants are totally removed after $30 \mathrm{~min}$ by photo-Fenton with iron-impregnated faujasite while a longer period is necessary by photocatalysis with $\mathrm{TiO}_{2}$. For instance, bisphenol A, carbamazepine, clarythromycine, diclofenac, estrone, ketoprofen, lidocaine, naproxen and triclosan are totally removed after 30 min using the photo-Fenton process for the two initial concentrations. Conversely, only estrone, naproxen and triclosan reach $X(30 \mathrm{~min})=100 \%$ when treated by photocatalysis. The temporal evolutions of the NPOC values support these results (Table 4). The NPOC decreases with the time of process from 3.5 to $3.0 \mathrm{mg} \mathrm{C} \mathrm{L}^{-1}$ and $2.7 \mathrm{mg} \mathrm{C} \mathrm{L}^{-1}$ after $30 \mathrm{~min}$ and $6 \mathrm{~h}$ of photocatalysis. In the presence of ironimpregnated faujasite, the NPOC values of the solution after $30 \mathrm{~min}$ and $6 \mathrm{~h}$ of treatment range between 2.6 and $2.4 \mathrm{mg} \mathrm{C} \mathrm{L}{ }^{-1}$. The fastest degradation by photo-Fenton in the presence of iron-impregnated faujasite may arise from the larger amount of adsorbed micropollutants and/ or the higher production of radicals. A correlation between the time needed to degrade the pollutant and the contaminant surface coverage was already reported for both photocatalysis and photo-Fenton processes [34, 43, 44]. The previous studies highlighted that a high adsorption of contaminant increases the efficiency of the degradation process. For the second explanation, it can be noticed that the hydroxyl radicals are the major active species during the oxidation reactions. It is assumed that the photoFenton process produces a larger amount of $\mathrm{OH}$ than the photocatalytic reaction. The additional formation of $\mathrm{OH}$ comes from Fenton reaction through the presence of $\mathrm{H}_{2} \mathrm{O}_{2}$. Our results corroborate the other measurements, demonstrating that photo-Fenton systems produced better degradation of the contaminants over $\mathrm{TiO}_{2}$ photocatalysis processes [28-31]. Dai et al. [45] reached the same conclusion when conducting degradation experiments over carbamazepine $\left(1000 \mathrm{\mu g} \mathrm{L}^{-1}\right)$. The degradation efficiencies proceeded in the following order ascending sequence: UV photolysis $<\mathrm{UV} / \mathrm{H}_{2} \mathrm{O}_{2}<$ Fenton $<\mathrm{UV} / \mathrm{TiO}_{2}<\mathrm{UV} /$ photo-Fenton. Our results follow the same order with the real water containing the cocktail of microcontaminants.

It is also relevant to conduct an economical evaluation of both AOPs systems to evaluate which is the better one in terms of cost. In a first approach, the costs of the reagents is estimated. The costs of reagents $\left(\mathrm{TiO}_{2}\right.$, faujasite, $\mathrm{H}_{2} \mathrm{O}_{2}$, iron (III) nitrate nonahydrate) are calculated as the concentration used (C) multiplied by the unit price of the product $(\mathrm{P})$. They read as $[\mathrm{C} \times \mathrm{P}]$. For photocatalysis process $[\mathrm{C} \times \mathrm{P}]_{\text {Photocatalysis }}$ is mainly due to the $\mathrm{TiO}_{2}$. Conversely, for photo-Fenton process, $[\mathrm{C} \times \mathrm{P}]_{\text {Photo-Fenton }}$ takes into account the costs of the faujasite, the iron (III) nitrate nonahydrate used to prepare the iron-impregnated faujasite and the hydrogen peroxide.

Photocatalysis cost $=[\mathrm{C} \times \mathrm{P}]_{\mathrm{Photocatalysis}}=\mathrm{C}_{\mathrm{TiO}_{2}} \times \mathrm{P}_{\mathrm{TiO}_{2}}$

$$
\begin{aligned}
\text { Photo-Fenton cost }= & \mathrm{C}_{\text {faujasite }} \times \mathrm{P}_{\text {faujasite }}+\mathrm{C}_{\mathrm{Fe}\left(\mathrm{NO}_{3}\right)^{3}} \\
& \times \mathrm{P}_{\mathrm{Fe}\left(\mathrm{NO}_{3}\right)^{3}}+\mathrm{C}_{\mathrm{H}_{2} \mathrm{O}_{2}} \times \mathrm{P}_{\mathrm{H}_{2} \mathrm{O}_{2}}
\end{aligned}
$$

According to the market, the price of $\mathrm{TiO}_{2}$ ranges between 1800 and 2000 euros/ton, the price for faujasite is equal to $75-140$ euros/ton, $\mathrm{Fe}\left(\mathrm{NO}_{3}\right)_{3}$ costs $500-800$ 
euros/ton, while $\mathrm{H}_{2} \mathrm{O}_{2}$ costs 0.747 euro/kg. The calculation is conducted for 1 ton of $\mathrm{TiO}_{2}$ for photocatalysis and 1 ton of faujasite for photo-Fenton. For the calculation, it is considered that for 1 ton of catalyst $\left(\mathrm{TiO}_{2}\right.$ or iron-impregnated faujasite), $\mathrm{TiO}_{2}$ has a cost of 2000 euros, faujasite 120 euros, $\mathrm{Fe}\left(\mathrm{NO}_{3}\right)_{3}, 120$ euros (20 wt\% of iron), and $\mathrm{H}_{2} \mathrm{O}_{2} 177$ euros $(0.007 \mathrm{~mol} / \mathrm{L}$ or $0.238 \mathrm{~g} / \mathrm{L})$. The photocatalysis cost $[\mathrm{C} \times \mathrm{P}$ ]$_{\text {Photocatalysis }}$ is evaluated as 2000 euros/ton of $\mathrm{TiO}_{2}$ while the photo-Fenton cost [C $\times \mathrm{P}]_{\text {Photo-Fenton }}$ is equal to 417 euros/ ton of faujasite. It can be deduced that the total price of the reagents used for photo-Fenton process is substantially less expensive than that used for photocatalysis. This is mainly due to the expansive price of $\mathrm{TiO}_{2} \mathrm{P} 25$.

In the previous calculation, only the cost of the reagents was estimated. The total cost (TC) of the process is also affected by the operating cost (OC) of the process, which depends on the time of reaction $t_{R^{\prime}}$ as well as the amortization costs of the investment (AC). In the present study, since we use a batch laboratory scale process, the price of several parameters is not easy to estimate in real plant conditions. The maintenance cost, working hours per day, amortization cost are some examples. To evaluate the operating cost, we use the approach developed by SantosJuanes Jorda et al. [46]. This equation was developed for a pilot plant based in Almeria (Spain). The total cost per $\mathrm{m}^{3}$ of water treated is calculated as [46]:

$$
\begin{aligned}
\mathrm{TC}\left(\text { euros } / \mathrm{m}^{3}\right)= & \mathrm{AC}+\mathrm{OC}=0.0712+[\mathrm{C} \times \mathrm{P}] \\
& +1.2329 \times \mathrm{t}_{\mathrm{R}}+0.0042 \times \mathrm{t}_{\mathrm{R}}^{2}
\end{aligned}
$$

This equation shows the linear and quadratic effects of the reaction time $t_{R}$ on the total cost of the process. The Table 6 gives the economic and cost evaluation of the photocatalysis and photo-Fenton processes for treatment of the micropollutants. The time of reaction $t_{R}$ depends on the process and also on the nature of the micropollutants. For this reason, the TC are calculated for $t_{R}$ varying between 0.5 and $6 \mathrm{~h}$ for both processes. The results indicate that the total cost of the photocatalysis process is higher than that of photo-Fenton regardless of the reaction time. When $t_{R}$ equals $30 \mathrm{~min}$, the cost of photocatalysis is the double of that of photo-Fenton. Conversely, after $6 \mathrm{~h}$

Table 6 Economic and cost evaluation of the photocatalysis and photo-Fenton processes for treatment of the micropollutants. TC is the total cost per $\mathrm{m}^{3}$ of water treated

\begin{tabular}{lll}
\hline Time of reaction $\mathrm{t}_{\mathrm{R}}(\mathrm{h})$ & $\begin{array}{l}\text { Photocatalysis TC (euros/ } \\
\left.\mathrm{m}^{3}\right)\end{array}$ & $\begin{array}{l}\text { Photo-Fenton } \\
\mathrm{TC}\left(\text { euros } / \mathrm{m}^{3}\right)\end{array}$ \\
\hline 0.5 & 2.6 & 1.1 \\
1 & 3.3 & 1.7 \\
3 & 5.8 & 4.2 \\
6 & 9.6 & 8.0 \\
\hline
\end{tabular}

of process the cost of the two processes becomes closer $(\mathrm{TC}($ photocatalysis $) / \mathrm{TC}$ (photo-Fenton $)=1.19)$. Based on these considerations, it can be concluded that the photoFenton process for the removal of the 21 micropollutants is the cheaper. This is particularly true since the majority of the micropollutants are removed after $30 \mathrm{~min}$ of photoFenton process while it takes $6 \mathrm{~h}$ to reach the complete removal using photocatalysis.

For ibuprofen, ketoprofen, and triclosan, the initial concentrations are similar between the two waters (Table 3). These pollutants can be analyzed to assess the influence of the water matrix composition on the adsorption and photodegradation processes (photocatalysis and photoFenton). Recent studies showed that the photocatalytic performances are adversely impacted by the wastewater matrix [20-23]. In general, the constituents present in the wastewater lowered the degradation rate of the micropollutants due to the quenching of the $\mathrm{OH}$ by the organic matters, humic acid, inorganic ions such as $\mathrm{Cl}^{-}, \mathrm{NH}_{4}^{+}$, $\mathrm{NO}_{3}{ }^{-}, \mathrm{HCO}_{3}{ }^{-}$[23]. Here, in both cases, the photocatalytic treatment leads to the disappearance of triclosan after 30 min of irradiation (Fig. 3). For ketoprofen, the complete removal $(X=100 \%)$ takes place during $6 \mathrm{~h}$ of photocatalysis for the two samplings. More remarkably, the removal percentages after $30 \mathrm{~min}$ of treatment are very close, i.e. $X(30 \mathrm{~min})=8$ and $10 \%$. For ibuprofen, the photocatalytic removal efficiencies remain similar during the whole process: $X(30 \mathrm{~min})=9-10 \%$ and $X(6 \mathrm{~h})=93-94 \%$. These data emphasise that the photocatalytic removal of the micropollutants is not affected by the water matrix. This result was expected since the physicochemical characteristics of the two water samples do not differ significantly in terms of macropollutants (Table 2). The same trend is reported also with the photo-Fenton process. For the two waters, the photo-Fenton treatment produces the disappearance of triclosan after $30 \mathrm{~min}$. The adsorbed amounts of ketoprofen onto the iron-impregnated faujasite remain very close $\left(R_{a}=58\right.$ and $\left.62 \%\right)$. In the special case of ibuprofen, the kinetic of degradation does not quantitatively differ between the two periods: $X(30 \mathrm{~min})=90-100 \%$ and $X(6 h)=94-100 \%$.

\section{Conclusions}

The aim of this paper was to study and compare the degradation of a large variety of micropollutants in real water samples from a river using the photocatalysis conventional $\mathrm{TiO}_{2} / \mathrm{UV}$ system and iron-impregnated faujasite photo-Fenton process. The samples have been collected from the Meurthe River in the vicinity of the city of Nancy in France. To address the influence of the water 
matrix composition and the micropollutants concentrations, the sampling campaigns have been conducted at two different periods of the year. Twenty one micropollutants including 14 pharmaceutical compounds, 1 personal care product, 4 endocrine disruptors and 2 perfluorinated molecules have been detected, quantified and degraded. All the initial concentrations appear in the range of $\mathrm{n} \mathrm{L}^{-1}$ since they range between 0.8 and $140 \mathrm{ng} \mathrm{L}^{-1}$.

The adsorption of all the micropollutants is higher onto the iron-impregnated faujasite compared to that onto $\mathrm{TiO}_{2}$. This is attributed to the larger surface area of the iron-impregnated faujasite as compared to that of $\mathrm{TiO}_{2}$. The iron-impregnated faujasite offers superior photo-Fenton oxidation efficiency towards the degradation of the micropollutants over the $\mathrm{TiO}_{2}$ photocatalysis system. During $6 \mathrm{~h}$ of photocatalytic and photo-Fenton treatments, carbamazepine, carbamazepine-10,11-epoxide, clarithromycin, diclofenac, estrone, ketoprofen, lidocaine, naproxen and triclosan are totally removed by the two processes for the two initial concentrations. For the other micropollutants, the removal percentage is greater using the photo-Fenton process than with the photocatalytic degradation. A relation between the removal efficiency and log Kow of each micropollutant can be deduced from the data. For the pollutant with low log Kow (0.79), the total removal of the micropollutant occurs only with photocatalysis. For the micropollutants with log Kow between 2.16 and 3.1, the total removal of the micropollutants is obtained under both processes. For the micropollutants with log Kow larger than or equal to 3.3, the total removal of the microcontaminants can be only obtained by photo-Fenton.

The removal efficiency after $30 \mathrm{~min}$ of process is used to evaluate the kinetic of the two processes. For almost all the micropollutants, the contaminants are totally degraded after $30 \mathrm{~min}$ by photo-Fenton with iron-impregnated faujasite while a longer period is necessary by photocatalysis with $\mathrm{TiO}_{2}$. The fastest photo-Fenton degradation in the presence of iron-impregnated faujasite arises from the larger amount of adsorbed micropollutant onto the iron-impregnated faujasite and the higher production of radicals due to the addition of $\mathrm{H}_{2} \mathrm{O}_{2}$. This latter aspect need to be experimentally verified. In addition, the economical evaluation reveals that the photo-Fenton process is more economic as compared to photocatalysis process. This is due to the high price of $\mathrm{TiO}_{2}$ and the shorter time of reaction during photo-Fenton process.

Funding This work was financially supported by the Carnot Institute ICÉEL within the "STEP-Design project".

\section{Compliance with ethical standards}

Conflict of interest The authors declare that they have no conflict of interest.

\section{References}

1. Fatta-Kassinos D, Meric S, Nikolaou A (2011) Pharmaceutical residues in environmental waters and wastewater: current state of knowledge and future research. Anal Bioanal Chem 399:251-275

2. Richardson SD, Kimura SY (2016) Water analysis: emerging contaminants and current issues. Anal Chem 88:546-582

3. Kidd KA, Blanchfield PJ, Mills KH, Palace VP, Evans RE, Lazorchak JM, Flick RW (2007) Collapse of a fish population after exposure to a synthetic estrogen. Proc Natl Acad Sci USA 104:8897-8901

4. Trapido M, Epold I, Bolobajev J, Dulova N (2014) Emerging micropollutants in water/wastewater: growing demand on removal technologies. Environ Sci Pollut R 21:12217-12222

5. Zhang Y, Geißen SU, Gal C (2008) Carbamazepine and diclofenac: removal in wastewater treatment plants and occurrence in water bodies. Chemosphere 73:1151-1161

6. Tran NH, Gin KYH (2017) Occurrence and removal of pharmaceuticals, hormones, personal care products, and endocrine disrupters in a full-scale water reclamation plant. Sci Total Environ 599-600:1503-1516

7. Ternes TA (1998) Occurrence of drugs in German sewage treatment plants and rivers. Water Res 32:3245-3260

8. Stackelberg PE, Furlong ET, Meyer MT, Zaugg SD, Henderson AK, Reissman DB (2004) Persistence of pharmaceutical compounds and other organic wastewater contaminants in a conventional drinking-water-treatment plant. Sci Total Environ 329:99-113

9. Ayoub H (2018) Heterogeneous photo-Fenton process for removal of micropollutants at very low concentration from Meurthe river. Ph.D. thesis, University of Lorraine, France

10. Rossner A, Snyder SA, Knappe DRU (2009) Removal of emerging contaminants of concern by alternative adsorbents. Water Res 43:3787-3796

11. Pendergast MM, Hoek EMV (2011) A review of water treatment membrane nanotechnologies. Energy Environ Sci 4:1946-1971

12. Kurniawan TA, Sillanpaa MET, Sillanpaa M (2012) Nanoadsorbents for remediation of aquatic environment: local and practical solutions for global water pollution problems. Crit Rev Environ Sci Technol 42:1233-1295

13. Wei Q, Yang DL, Fan MH, Harris HG (2013) Applications of nanomaterial-based membranes in pollution control. Crit Rev Environ Sci Technol 43:2389-2438

14. Ferrando-Climent L, Gonzalez-Olmos R, Anfruns A, Aymerich I, Corominas L, Barcelo D, Rodriguez-Mozaz S (2017) Elimination study of the chemotherapy drug tamoxifen by different advanced oxidation processes: transformation products and toxicity assessment. Chemosphere 168:284-292

15. Jimenez S, Andreozzi M, Mico MM, Alvarez MG, Contreras S (2019) Produced water treatment by advanced oxidation processes. Sci Total Environ 666:12-21

16. Anjali R, Shanthakumar S (2019) Insights on the current status of occurrence and removal of antibiotics in wastewater by advanced oxidation processes. J Environ Manage 246:51-62

17. Youssef Z, Colombeau L, Yesmurzayeva N, Baros F, Vanderesse R, Hamieh T, Toufaily J, Frochot C, Roques-Carmes T (2018) Dyesensitized nanoparticles for heterogeneous photocatalysis: cases studies with $\mathrm{TiO}_{2}, \mathrm{ZnO}$, fullerene and graphene for water purification. Dyes Pigm 159:49-71 
18. Herrmann JM (2005) Heterogeneous photocatalysis: state of the art and present applications. Top Catal 34:49-65

19. Gaya UI, Abdullah AH (2008) Heterogeneous photocatalytic degradation of organic contaminants over titanium dioxide: a review of fundamentals, progress and problems. J Photochem Photobiol C Photochem Rev 9:1-12

20. Lado Ribeiro AR, Moreira NFF, Puma GL, Silva AMT (2019) Impact of water matrix on the removal of micropollutants by advanced oxidation technologies. Chem Eng J 363:155-173

21. Moreira NFF, Sampaio MJ, Ribeiro AR, Silva CG, Faria JL, Silva AMT (2019) Metal-free $\mathrm{g}-\mathrm{C}_{3} \mathrm{~N}_{4}$ photocatalyis of organic micropollutants in urban wastewater under visible light. Appl Catal $B$ Environ 248:184-192

22. Ye Y, Bruning H, Liu W, Rijnaarts H, Yntema D (2019) Effect of dissolved natural organic matter on the photocatalytic micropollutant removal performance of $\mathrm{TiO}_{2}$ nanotube array. J Photochem Photobiol A Chem 371:216-222

23. Sornalingam $K$, McDonagh A, Zhou JL, Abu Hasan Johir M, Boshir Ahmed M (2018) Photocatalysis of estrone in water and wastewater: comparison between $\mathrm{Au}-\mathrm{TiO}_{2}$ nanocomposite and $\mathrm{TiO}_{2}$, and degradation by-products. Sci Total Environ 610-611:521-530

24. Moreira NFF, Sousa JM, Macedo G, Ribeiro AR, Barreiros L, Pedrosa M, Faria JL, Pereira MFR, Castro-Silva S, Segundo MA, Manaia CM, Nunes OC, Silva AMT (2016) Photocatalytic ozonation of urban wastewater and surface water using immobilized $\mathrm{TiO}_{2}$ with LEDs: micropollutants, antibiotic resistance genes and estrogenic activity. Water Res 94:10-22

25. Teixeira S, Gurke R, Eckert H, Kuhn K, Fauler J, Cuniberti G (2016) Photocatalytic degradation of pharmaceuticals present in conventional treated wastewater by nanoparticle suspensions. J Environ Chem Eng 4:287-292

26. Miralles-Cuevas S, Oller I, Ruiz Aguirre A, Sánchez Pérez JA, Malato Rodríguez S (2014) Removal of pharmaceuticals at microg $\mathrm{L}^{-1}$ by combined nanofiltration and mild solar photoFenton. Chem Eng J 239:68-74

27. Giannakis S, Gamarra Vives FA, Grandjean D, Magnet A, De Alencastro LF, Pulgarin C (2015) Effect of advanced oxidation processes on the micropollutants and the effluent organic matter contained in municipal wastewater previously treated by three different secondary methods. Water Res 84:295-306

28. Lofrano G, Rizzo L, Grassi M, Belgiorno V (2009) Advanced oxidation of catechol: a comparison among photocatalysis, Fenton and photo-Fenton processes. Desalination 249:878-883

29. Elmolla ES, Chaudhuri M (2010) Comparison of different advanced oxidation processes for treatment of antibiotic aqueous solution. Desalination 256:43-47

30. Mahdi Ahmed M, Brienza M, Goetz V, Chiron S (2014) Solar photo-Fenton using peroxymonosulfate micropollutants removal from domestic wastewater: comparison with heterogeneous $\mathrm{TiO}_{2}$ photocatalysis. Chemosphere 117:256-261

31. Alalm MG, Tawfik A, Ookawara S (2015) Comparison of solar $\mathrm{TiO}_{2}$ photocatalysis and solar photo-Fenton for treatment of pesticides industry wastewater: operational conditions, kinetics, and cost. J Water Process Eng 8:55-63

32. Moreira NFF, Narciso-da-Rocha C, Polo-Lopez MI, PastranaMartinez LM, Faria JL, Manaia CM, Fernandez-lbanez P, Nunes OC, Silva AMT (2018) Solar treatment $\left(\mathrm{H}_{2} \mathrm{O}_{2}, \mathrm{TiO}_{2}-\mathrm{P} 25\right.$ and GO$\mathrm{TiO}_{2}$ photocatalysis, photo-Fenton) of organic micropollutants, human pathogen indicators, antibiotic resistant bacteria and related genes in urban wastewater. Water Res 135:195-206
33. Ayoub H, Roques-Carmes T, Potier O, Koubaissy B, Pontvianne S, Lenouvel A, Guignard C, Mousset E, Poirot $H$, Toufaily J, Hamieh T (2018) Iron impregnated zeolite catalyst for efficient removal of micropollutants at very low concentration from Meurthe river. Environ Sci Pollut Res 25:34950-34967

34. Kassir M, Roques-Carmes T, Hamieh T, Toufaily J, Akil M, Barres $O$, Villiéras $F(2015)$ Improvement of the photocatalytic activity of $\mathrm{TiO}_{2}$ induced by organic pollutant enrichment at the surface of the organografted catalyst. Colloids Surf A 485:73-83

35. Kassir M, Roques-Carmes T, Pelletier M, Bihannic I, Alem H, Hamieh T, Toufaily J, Villiéras F (2017) Adsorption and photocatalysis activity of $\mathrm{TiO}_{2}$ /bentonite composites. Desalin Water Treat 98:196-215

36. Blin JL, Stébé MJ, Roques-Carmes T (2012) Use of ordered mesoporous titania with semi-crystalline framework as photocatalyst. Colloids Surf A 407:177-185

37. Mostofa KMG, Yoshioka T, Konohira E, Tanoue E (2007) Photodegradation of fluorescent dissolved organic matter in river waters. Geochem J 41:323-331

38. Baker A, Cumberland SA, Bradley C, Buckley C, Bridgeman J (2015) To what extent can portable fluorescence spectroscopy be used in the real-time assessment of microbial water quality. Sci Total Environ 532:14-19

39. Qiao W, Wang X, Liu X, Zhen X, Guo J, Wang S, Yang F, Chen G, Zhang $B$ (2017) Characterization of dissolved organic matter in deep geothermal water from burial depths based on threedimensional fluorescence spectra. Water 9:266-279

40. Bernabeu A, Vercher RF, Santos-Juanes L, Simon PJ, Lardin C Martinez MA, Vicente JA, Gonzalez R, Llosa C, Arques A, Amat AM (2011) Solar photocatalysis as a tertiary treatment to remove emerging pollutants from wastewater treatment plant effluents. Catal Today 161:235-240

41. Niu J, Zhang L, Li Y, Zhao J, Lys S, Xiao K (2013) Effects of environmental factors on sulfamethoxazole photodegradation under simulated sunlight irradiation kinetics and mechanism. J Environ Sci 25:1098-1106

42. Cai Q, Hu J (2017) Decomposition of sulfamethoxazole and trimethoprim by UVA/LED/TiO 2 photocatalysis: decomposition pathways, residual antibacterial activity and toxicity. J Hazard Mater 323:527-536

43. Inumaru K, Murashima M, Kasahara T, Yamanaka S (2004) Enhanced photocatalytic decomposition of 4-nonylphenol by surface-organografted $\mathrm{TiO}_{2}$ : a combination of molecular selective adsorption and photocatalysis. Appl Catal B 52:275-280

44. Sakai T, Da Loves A, Okada T, Mishima S (2013) Titania/ $C_{n} T A B$ nanoskeleton as adsorbent and photocatalyst for removal of alkylphenols dissolved in water. J Hazard Mater 248:487-495

45. Dai CM, Zhou XF, Zhang YL, Duan YP, Qiang ZM, Zhang TC (2012) Comparative study of the degradation of carbamazepine in water by advanced oxidation processes. Environ Technol 33:1101-1109

46. Santos-Juanes Jorda L, Ballesteros Martin MM, Ortega Gomez E, Cabrera Reina A, Roman Sanchez IM, Casas Lopez JL, Sanchez Perez JA (2011) Economic evaluation of the photo-Fenton process. Mineralization level and reaction time: the keys for increasing plant efficiency. J Hazard Mater 186:1924-1929

Publisher's Note Springer Nature remains neutral with regard to jurisdictional claims in published maps and institutional affiliations. 